\title{
Memantine Rescues Transient Cognitive Impairment Caused by High-Molecular-Weight $A \beta$ Oligomers But Not the Persistent Impairment Induced by Low-Molecular-Weight Oligomers
}

\author{
Cláudia P. Figueiredo, ${ }^{1,2 \star}$ Julia R. Clarke, ${ }^{2 \star}$ José Henrique Ledo, ${ }^{2}$ Felipe C. Ribeiro, ${ }^{1}$ Carine V. Costa, ${ }^{2}$ Helen M. Melo, ${ }^{2}$ \\ Axa P. Mota-Sales, ${ }^{2}$ Leonardo M. Saraiva, ${ }^{2}$ William L. Klein, ${ }^{3}$ Adriano Sebollela, ${ }^{2}$ Fernanda G. De Felice, ${ }^{2}$ \\ and Sergio T. Ferreira ${ }^{2}$ \\ ${ }^{1}$ School of Pharmacy and ${ }^{2}$ Institute of Medical Biochemistry, Federal University of Rio de Janeiro, Rio de Janeiro, RJ 21944-590, Brazil, and ${ }^{3}$ Department of \\ Neurobiology, Northwestern University, Evanston, Illinois 60208
}

Brain accumulation of soluble amyloid- $\beta$ oligomers $(\mathrm{A} \beta 0 \mathrm{Os})$ has been implicated in synapse failure and cognitive impairment in Alzheimer's disease $(\mathrm{AD})$. However, whether and how oligomers of different sizes induce synapse dysfunction is a matter of controversy. Here, we report that low-molecular-weight (LMW) and high-molecular-weight (HMW) A $\beta$ oligomers differentially impact synapses and memory. A single intracerebroventricular injection of LMW A $\beta 0 \mathrm{~s}(10 \mathrm{pmol})$ induced rapid and persistent cognitive impairment in mice. On the other hand, memory deficit induced by HMW A $\beta 0 \mathrm{~s}(10 \mathrm{pmol})$ was found to be reversible. While memory impairment in LMW oligomer-injected mice was associated with decreased hippocampal synaptophysin and GluN2B immunoreactivities, synaptic pathology was not detected in the hippocampi of HMW oligomer-injected mice. On the other hand, HMW oligomers, but not LMW oligomers, induced oxidative stress in hippocampal neurons. Memantine rescued both neuronal oxidative stress and the transient memory impairment caused by HMW oligomers, but did not prevent the persistent cognitive deficit induced by LMW oligomers. Results establish that different $\mathrm{A} \beta$ oligomer assemblies act in an orchestrated manner, inducing different pathologies and leading to synapse dysfunction. Furthermore, results suggest a mechanistic explanation for the limited efficacy of memantine in preventing memory loss in AD.

\section{Introduction}

Amyloid- $\beta$ peptide $(\mathrm{A} \beta)$ monomers self-assemble to form multiple types of soluble oligomers (A $\beta \mathrm{O}$ ) including lowmolecular-weight (LMW; dimers, trimers, tetramers) and highmolecular-weight (HMW) species ranging in mass from $\sim 54$ to $150 \mathrm{kDa}$ (Ferreira and Klein, 2011; Larson and Lesne, 2012). Although $\mathrm{A} \beta \mathrm{O}$ s are increasingly recognized as key mediators of

Received Jan. 31, 2013; revised April 8, 2013; accepted April 23, 2013.

Author contributions: C.P.F., J.R.C., W.L.K., A.S., F.G.D.F., and S.T.F. designed research; C.P.F., J.R.C., J.H.L., F.C.R., C.V.C., H.M.M., A.P.M.-S., L.M.S., A.S., and F.G.D.F. performed research; W.L.K. and S.T.F. contributed unpublished reagents/analytic tools; C.P.F., J.R.C., J.H.L., F.C.R., H.M.M., A.S., F.G.D.F., and S.T.F. analyzed data; C.P.F., J.R.C., A.S., F.G.D.F., and S.T.F. wrote the paper.

This work was supported by grants from the National Institute for Translational Neuroscience (Brazil) (S.T.F.) Conselho Nacional de Desenvolvimento Científico e Tecnológico (A.S., C.P.F., J.R.C., S.T.F., F.G.D.F.), Fundação de Amparo à Pesquisa do Estado do Rio de Janeiro (C.P.F., J.R.C., S.T.F., F.G.D.F.), Human Frontier Science Program (F.G.D.F.), and John Simon Guggenheim Memorial Foundation (F.G.D.F.). We thank Maíra S. Oliveira and Mariângela M. Viana for technical support and Ana Claudia Rangel for competent lab and project management.

${ }^{*}$ C.P.F. and J.R.C. contributed equally to this work.

W.L.K. is cofounder of Acumen Pharmaceuticals, which has been licensed by Northwestern University to develop Amyloid-derived diffusible ligand (ADDL) technology for Alzheimer's therapeutics and diagnostics.

This article is freely available online through the J Neurosci Author Open Choice option.

Correspondence should be addressed to Sergio T. Ferreira or Fernanda G. De Felice, Institute of Medical Biochemistry, Federal University of Rio de Janeiro, Rio de Janeiro, RJ 21944-590, Brazil. E-mail: ferreira@bioqmed.ufrj.br or felice@bioqmed.ufri.br.

DOI:10.1523/JNEUROSCI.0482-13.2013

Copyright $\odot 2013$ the authors $\quad 0270-6474 / 13 / 339626-09 \$ 15.00 / 0$ synaptic and cognitive dysfunction in Alzheimer's disease (AD) (Ferreira et al., 2007; Haass and Selkoe, 2007; Ferreira and Klein, 2011; Benilova et al., 2012; Selkoe, 2012), the molecular identity and the mechanisms by which oligomers impact synapses and lead to cognitive impairment are still controversial (Walsh and Selkoe, 2007; Glabe, 2008; Benilova et al., 2012).

Elucidating the neuronal impact of different $A \beta$ oligomer species would be an important step to improving our understanding of mechanisms of pathogenesis and to driving the development of novel approaches to prevent oligomer toxicity and memory impairment in AD (Mucke and Selkoe, 2012). Since low- and high-molecular-weight oligomers have been shown to accumulate in the AD brain (Gong et al., 2003; Shankar et al., 2008), we hypothesized that both forms of $A \beta$ assemblies act as pathogenic species in $\mathrm{AD}$, perhaps causing neuronal dysfunction through distinct mechanisms.

Here, we investigate the impact of HMW and LMW A $\beta$ oligomers, fractionated by size exclusion chromatography (SEC) HPLC, on memory and synapse pathology in mice. A single intracerebroventricular injection of a preparation containing both HMW and LMW A $\beta \mathrm{Os}$ ( $10 \mathrm{pmol}$ ) induced memory impairment in mice $24 \mathrm{~h}$ after injection, which persisted for longer than 2 weeks after injection. Similar cognitive impairment was induced in mice injected intracerebroventricularly with LMW A $\beta$ Os. In 
contrast, $\mathrm{HMW} \mathrm{A} \beta \mathrm{O}$ s induced a transient memory deficit that was fully recovered by $14 \mathrm{~d}$ after injection. The distinct effects of low- and high-molecular-weight oligomers on memory were accompanied by differential impacts on synapses. Furthermore, we tested the efficacy of memantine, clinically used to treat $\mathrm{AD}$, in preventing the impact of both HMW and LMW A $\beta O$ s. Memantine blocked neuronal oxidative stress and transient memory impairment caused by HMW oligomers, but had no effect on the persistent memory deficit induced by LMW oligomers. These results demonstrate that LMW and HMW oligomers differentially impact synapses and memory in mice and suggest an explanation for the limited clinical efficacy of memantine in $\mathrm{AD}$.

\section{Materials and Methods}

Preparation and fractionation of $A \beta O$ s. Oligomers were prepared from synthetic $\mathrm{A} \beta_{1-42}$ peptide (American Peptide) as described previously (Lambert et al., 1998). Briefly, the peptide was first solubilized in hexafluoroisopropanol, and the solvent was evaporated to produce dried films, which were subsequently dissolved in sterile anhydrous dimethylsulfoxide to make a $5 \mathrm{~mm}$ solution. This solution was diluted to $100 \mu \mathrm{M}$ in ice-cold PBS and incubated for $16 \mathrm{~h}$ at $4^{\circ} \mathrm{C}$. The preparation was centrifuged at $14,000 \times g$ for $10 \mathrm{~min}$ at $4^{\circ} \mathrm{C}$ to remove insoluble aggregates (protofibrils and fibrils), and the supernatants containing soluble $\mathrm{A} \beta$ oligomers were stored at $4^{\circ} \mathrm{C}$. Protein concentration was determined using the BCA assay (Thermo Scientific Pierce). Preparations were routinely characterized by HPLC size-exclusion chromatography under nondenaturing conditions and, occasionally, by SDS-PAGE/Western blot using anti-A $\beta 6 \mathrm{E} 10$ (Abcam) or anti-A $\beta$ oligomer NU4 (Lambert et al., 2007) antibodies. SEC analysis reveals that $A \beta O$ preparations comprise a mixture of high-molecular-weight (molecular masses ranging from 80 to $150 \mathrm{kDa}$ ) and low-molecular-weight (average molecular mass, $\sim 10 \mathrm{kDa}$ ) oligomers, and are virtually devoid of $A \beta$ monomers (see Fig. $2 A$ ). Lack of monomers in $\mathrm{A} \beta \mathrm{O}$ preparations is consistent with the high tendency of $A \beta_{1-42}$ to self-aggregate in aqueous medium, and also with previously reported SEC profiles of oligomers prepared using the same protocol we used (Chromy et al., 2003; Lacor et al., 2004; Sebollela et al., 2012). Oligomers were used within $48 \mathrm{~h}$ of preparation.

$\mathrm{A} \beta \mathrm{O}$ preparations were separated into low (LMW $\mathrm{A} \beta \mathrm{Os}$ ) and high (HMW A $\beta \mathrm{O}$ ) molecular weight fractions by size-exclusion chromatography using a GPC100 column (Eichrom) connected to an LC-10 Shimadzu HPLC system. The column was equilibrated in PBS, pH 7.0, and $100 \mu$ l of freshly prepared $\mathrm{A} \beta O$ s were loaded at a flow rate of $0.5 \mathrm{ml} / \mathrm{min}$. Elution was monitored by absorbance at $280 \mathrm{~nm}$ and fluorescence emission (excitation, $275 \mathrm{~nm}$; emission, $305 \mathrm{~nm}$ ). Fractions $(100 \mu \mathrm{l})$ were collected, and protein content was determined using the BCA assay (Thermo Scientific Pierce). Apparent molecular masses of $A \beta$ oligomer peaks were estimated using five protein standards ( $\beta$-amylase, 200 $\mathrm{kDa}$; alcohol dehydrogenase, $150 \mathrm{kDa}$; BSA, $66 \mathrm{kDa}$; carbonic anhydrase, $29 \mathrm{kDa}$; and cytochrome C, $12.4 \mathrm{kDa}$; Sigma). Plasmid DNA and YYG tripeptide were used to determine void and total included volumes of the column, respectively.

Animals and intracerebroventricular injections. Three-month-old male Swiss mice were used. Animals were housed in groups of five in each cage with free access to food and water, under a $12 \mathrm{~h}$ light/dark cycle with controlled room temperature and humidity. All procedures followed the Principles of Laboratory Animal Care from the National Institutes of Health and were approved by the Institutional Animal Care and Use Committee of the Federal University of Rio de Janeiro (protocol \#IBqM 041/2011).

For intracerebroventricular injection of $\mathrm{A} \beta \mathrm{O}$ s (or vehicle), animals were anesthetized for $7 \mathrm{~min}$ with $2.5 \%$ isoflurane (Cristália) using a vaporizer system, and were gently restrained only during the injection procedure. A 2.5 -mm-long needle was unilaterally inserted $1 \mathrm{~mm}$ to the right of the midline point equidistant from each eye and $1 \mathrm{~mm}$ posterior to a line drawn through the anterior base of the eyes (Laursen and Belknap, 1986; Figueiredo et al., 2011). Ten picomoles of unfractionated $\mathrm{A} \beta \mathrm{Os}$, HMW A $\beta$ Os, or LMW A $\beta$ Os (or an equivalent volume of vehicle) were injected in a final volume of $3 \mu \mathrm{l}$. Accurate placement of the needle into the right lateral ventricle was confirmed by macroscopic examination of dissected brains before immunohistochemistry. Mice showing any signs of misplaced injections or brain hemorrhage ( $\sim 5 \%$ of animals throughout our study) were excluded from further analysis. When indicated (see Results and figure legends), mice received 2, 10, or $20 \mathrm{mg} / \mathrm{kg}$ memantine once daily by gavage for $7 \mathrm{~d}$ before behavioral testing, or one single intraperitoneal injection of $0.1 \mathrm{mg} / \mathrm{kg}$ MK-801 $24 \mathrm{~h}$ before behavioral testing.

Novel object recognition test. The test was performed in an open field arena measuring $30 \times 30 \times 45 \mathrm{~cm}$. The floor of the arena was divided by lines into nine equal rectangles. Test objects were made of glass or plastic and had different shapes, colors, sizes, and textures. During behavioral sessions, objects were fixed to the box using tape to prevent displacement caused by exploratory activity of the animals. Preliminary tests showed that none of the objects used in our experiments evoked innate preference. Before training, each animal was submitted to a 5-min-long habituation session, in which they were allowed to freely explore the empty arena. During habituation sessions, the number of lines each animal crossed on the floor of the arena (number of crossings) and the number of rearings (elevation on rear paws, denoting exploratory behavior) were recorded to verify possible effects of treatments on locomotor/exploratory activities. No differences were found between experimental groups. In particular, under our experimental conditions, memantine, given alone or coadministered with either LMW A $\beta$ Os or HMW A $\beta$ Os had no effect on locomotor and exploratory activities (data not shown). Training consisted of a 5-min-long session during which animals were placed at the center of the arena in the presence of two identical objects. The time spent exploring each object was recorded by a trained researcher. Sniffing and touching the object were considered as exploratory behavior. The arena and objects were cleaned thoroughly between trials with $20 \%$ ethanol to eliminate olfactory cues. Two hours after training, animals were again placed in the arena for the test session, when one of the two objects used in the training session was replaced by a new one. Again, the time spent exploring familiar and novel objects was measured. Results were expressed as percentage of time exploring each object during the training or test session and were analyzed using a one-sample Student's $t$ test comparing the mean exploration time for each object with the fixed value of $50 \%$. By definition, animals that recognize the familiar object as such (i.e., learn the task) explore the novel object $>50 \%$ of the total time.

Dot blot assay. Twenty four hours after intracerebroventricular injection of $\mathrm{A} \beta \mathrm{O}$ s, bilateral hippocampi were dissected and immediately frozen in liquid nitrogen. For total protein extraction, samples were thawed and mechanically homogenized in Tris-buffered saline (TBS) containing protease inhibitor cocktail (Thermo Scientific). After centrifugation at $100,000 \times g$ for $1 \mathrm{~h}$ at $4^{\circ} \mathrm{C}$, supernatants were collected and immediately analyzed for the presence of soluble $\mathrm{A} \beta$ oligomers. Protein concentrations were determined using the BCA kit (Thermo Scientific), and a volume of sample containing $0.5 \mu \mathrm{g}$ protein was spotted onto a nitrocellulose membrane. Blots were incubated with $5 \%$ nonfat dry milk in Tween-TBS at room temperature for $2 \mathrm{~h}$ and then incubated for $2 \mathrm{~h}$ with the primary antibody (NU1, $1 \mu \mathrm{g} / \mathrm{ml}$ ) diluted in blocking buffer. Membranes were incubated with horseradish peroxidase-conjugated secondary antibody $(1: 50,000)$ at room temperature for $2 \mathrm{~h}$, revealed using SuperSignal West Pico chemiluminescent detection (Thermo Scientific) and analyzed using NIH Image J (Windows version).

Western immunoblot. Fourteen days after intracerebroventricular injection of HMW A $\beta$ Os, LMW A $\beta$ Os, or unfractionated $\mathrm{A} \beta \mathrm{O}$, bilateral hippocampi were dissected and immediately frozen in liquid nitrogen. For total protein extraction, samples were thawed and homogenized in buffer containing $25 \mathrm{~mm}$ Tris-HCl, pH 7.5, 150 mм NaCl, 1\% NP-40 (Invitrogen), 1\% sodium deoxicholate, 0.1\% SDS, 5 mм EDTA, 1\% Triton X-100, and phosphatase and protease inhibitor cocktail (Thermo Scientific Pierce). Protein concentrations were determined using the BCA kit, and samples containing $30 \mu \mathrm{g}$ protein were resolved in $4-20 \%$ polyacrylamide Tris-glycine gels (Invitrogen) and electrotransferred to nitrocellulose membranes at $300 \mathrm{~mA}$ for $1 \mathrm{~h}$. Blots were incubated with $5 \%$ nonfat dry milk in Tween-TBS at room temperature for $2 \mathrm{~h}$ and then incubated at $4^{\circ} \mathrm{C}$ overnight with the primary antibody diluted in blocking buffer. Primary antibodies used were anti-GluN1 (1:1000; Millipore), 
anti-synaptophysin (1:200; Cell Signaling Technology), anti-GluN2B (1:2000; Millipore), and anti- $\beta$-tubulin (1:10,000; Cell Signaling Technology). Membranes were then incubated with horseradish peroxidaseconjugated secondary antibody $(1: 50,000)$ at room temperature for $2 \mathrm{~h}$, probed with SuperSignal West Pico chemiluminescent detection (Thermo Fisher Scientific), and analyzed using NIH Image J.

Mature hippocampal neuronal cultures. Primary rat hippocampal neuronal cultures were prepared according to established procedures (De Felice et al., 2009) and were used after $18-21 \mathrm{~d}$ in vitro. Cultures were treated at $37^{\circ} \mathrm{C}$ for 3 h with 500 nM HMW A $\beta O s$, LMW A $\beta O$ s, or unfractionated $\mathrm{A} \beta \mathrm{O}$ s (or equivalent volumes of vehicle) and fixed with $4 \%$ paraformaldehyde. Immunocytochemistry was performed as described previously (Decker et al., 2010a; Jurgensen et al., 2011) using antiGluN1 or monoclonal $\mathrm{A} \beta \mathrm{O}$-selective NU4 antibody (Lambert et al., 2007) (1:1000) and anti-rabbit or anti-mouse Alexa Fluorconjugated secondary antibodies, respectively (Invitrogen; 1:1000). Coverslips were mounted using Prolong Gold (Invitrogen).

Generation of reactive oxygen species (ROS) was evaluated in live neurons as described previously (De Felice et al., 2007; Saraiva et al., 2010) using the fluorescent probe 5-(and-6)chloromethyl-2', $7^{\prime}-$

dichlorodihydrofluorescein diacetate, acetyl ester (CM-H2DCFDA) (Invitrogen), which is sensitive to various types of ROS, including peroxide, hydroxyl radical, peroxyl radicals, and peroxynitrite. Briefly, hippocampal neurons were maintained in Neurobasal medium supplemented with B27 (Invitrogen) for $20 \mathrm{~d}$. Cultures were incubated for $3 \mathrm{~h}$ at $37^{\circ} \mathrm{C}$ with vehicle or $500 \mathrm{~nm} \mathrm{~A} \beta \mathrm{Os}$, HMW A $\beta$ Os, or LMW A $\beta$ Os. When present, memantine was added $15 \mathrm{~min}$ before addition of $\mathrm{A} \beta \mathrm{O}$ fractions. ROS formation was assessed using $2 \mu \mathrm{M}$ CM-H2DCFDA (da-Silva et al., 2004) with $40 \mathrm{~min}$ of probe loading. After that, neurons were rinsed three times with warm PBS and twice with phenol red-free Neurobasal. Two experiments with independent neuronal cultures were performed, and results from the analysis of three images acquired per coverslip in each experimental condition (performed in duplicate) were combined for quantification of changes in neuronal ROS levels. Cells were imaged on a Nikon Eclipse TE 3000-U fluorescence microscope and images were digitally acquired using appropriate thresholding to eliminate background signal before histogram analysis. Quantitative analysis of immunofluorescence data was performed using Image J (NIH) as described previously (De Felice et al., 2007).

Immunohistochemistry. Mice were transcardially perfused with saline followed by fresh $4 \%$ formaldehyde. Brains were removed and postfixed for $24 \mathrm{~h}$ in the same solution, and then embedded in paraffin after dehydration and diaphanization. For immunohistochemistry, paraffinembedded brain tissue sections (3-5 $\mu \mathrm{m})$ were immersed in xylene for 10 min, rehydrated in absolute ethanol followed by $95 \%$ and $70 \%$ solutions of ethanol in water, and incubated with $3 \% \mathrm{H}_{2} \mathrm{O}_{2}$ in methanol for inactivation of endogenous peroxidase. Antigens were reactivated by treatment with $0.01 \mathrm{M}$ citrate buffer for $40 \mathrm{~min}$ at $95^{\circ} \mathrm{C}$. Slides were washed in PBS and incubated with primary antibody for $12-16 \mathrm{~h}$ at $2-8^{\circ} \mathrm{C}$. After washing with PBS, slides were incubated with biotinylated secondary antibody for $1 \mathrm{~h}$, washed twice with PBS, and incubated with streptavidin-biotin-peroxidase for $30 \mathrm{~min}$. Slides were then covered with $3,3^{\prime}$ diaminobenzidine solution $(0.06 \%$ DAB in PBS containing 2\% DMSO and $0.018 \% \mathrm{H}_{2} \mathrm{O}_{2}$ ) for 1 to $5 \mathrm{~min}$ or until a brown precipitate could be observed. Identical conditions and reaction times were used for slides from different animals to allow comparison between immunoreactivity
$24 \mathrm{~h}$
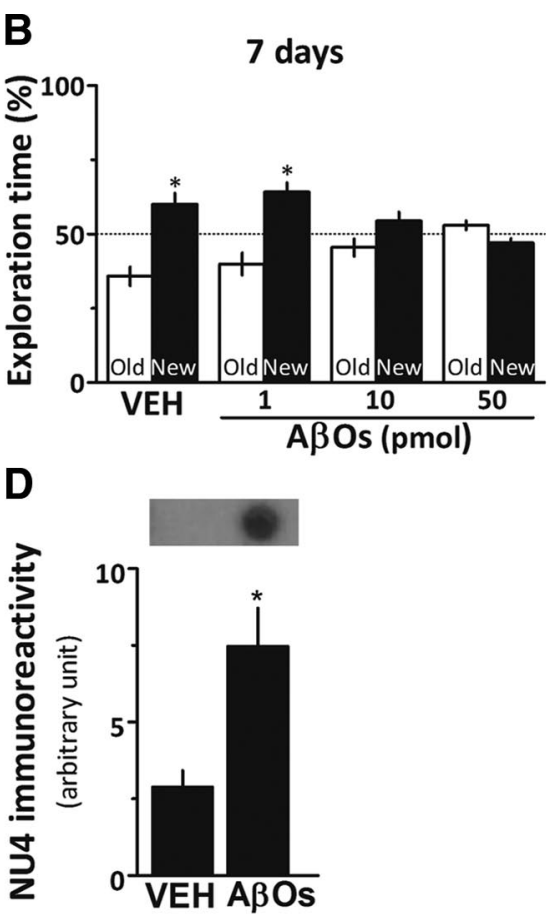

Figure 1. $\mathrm{A} \beta 0$ s induce cognitive impairment in mice. $\boldsymbol{A}-\boldsymbol{C}$, Male Swiss mice received a single intracerebroventricular injection of 1,10 , or $50 \mathrm{pmol} A \beta 0$ s [or vehicle (VEH)] and were tested in the novel object recognition task $24 \mathrm{~h}(\boldsymbol{A}), 7 \mathrm{~d}(\boldsymbol{B})$, or $14 \mathrm{~d}(\boldsymbol{C})$ after ( group). ${ }^{*} p<0.05$ (statistically significant difference; Student's $t$ test).

densities. Reaction was stopped by immersion of slides in distilled water. Counterstaining was performed with Harris hematoxilin.

Image analysis. Immunohistochemistry was performed in 3-5 $\mu \mathrm{m} \mathrm{sec-}$ tions from the dorsal hippocampus (1.6-2.4 $\mathrm{mm}$ posterior to the bregma). Three images of each hippocampal subregion (CA1, CA3, and dentate gyrus) were acquired using a Sight DS-5M-L1 digital camera (Nikon) connected to an Eclipse 50i light microscope (Nikon) at $400 \times$ magnification. An optical density (OD) threshold that best discriminated staining from the background was defined using NIH ImageJ $1.36 \mathrm{~b}$ imaging software as described previously (Figueiredo et al., 2011). Total pixel intensity was determined for each image, and data were expressed as OD.

\section{Results}

Intracerebroventricular injection of $\mathrm{A} \beta \mathrm{O}$ s induces cognitive impairment in mice

To determine the lowest dose of $\mathrm{A} \beta \mathrm{O}$ s that induced cognitive impairment in mice, animals were initially given a single intracerebroventricular injection of 1,10 , or $50 \mathrm{pmol} A \beta \mathrm{Os}$ (or vehicle) and were evaluated in the novel object recognition (OR) test $24 \mathrm{~h}$ or 7 or $14 \mathrm{~d}$ after injection (Fig. $1 A-C$ ). Animals that received injections of vehicle or $1 \mathrm{pmol} A \beta \mathrm{O}$ s learned the task at all evaluated postinjection intervals. In contrast, mice injected with 10 or $50 \mathrm{pmol} \mathrm{A} \beta \mathrm{O}$ s failed to acquire the OR memory when evaluated $24 \mathrm{~h}, 7 \mathrm{~d}$, or $14 \mathrm{~d}$ after injection. Based on these results, $10 \mathrm{pmol} \mathrm{A} \beta O$ s were used in subsequent experiments.

Because the hippocampus is involved in OR memory formation (Clarke et al., 2010), we investigated whether intracerebroventricular injected $\mathrm{A} \beta \mathrm{O}$ s indeed reached this region. As expected, the immunoreactivity of anti-A $\beta \mathrm{O}$ NU4 antibody (Lambert et al., 2007) was minimal in hippocampal extracts from vehicle-injected mice, whereas robust NU4 immunoreactivity 
A

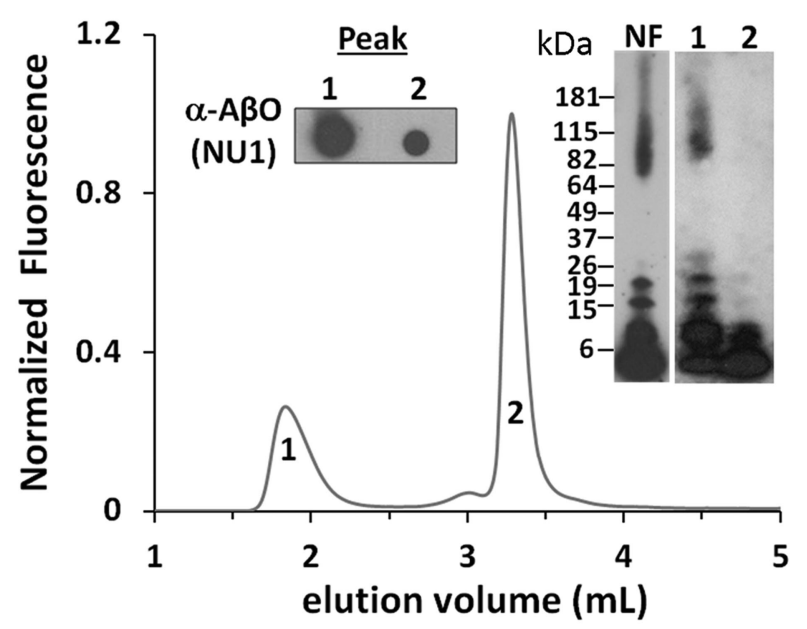

C

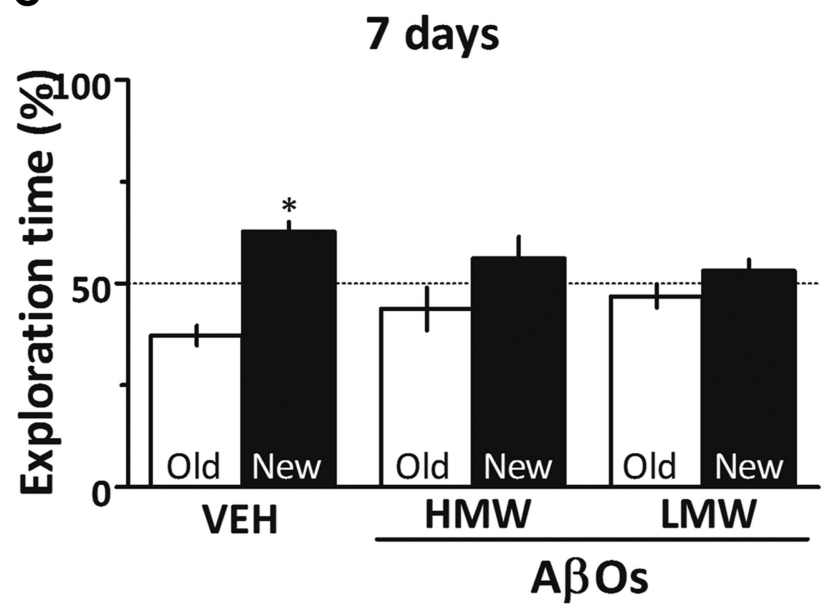

B

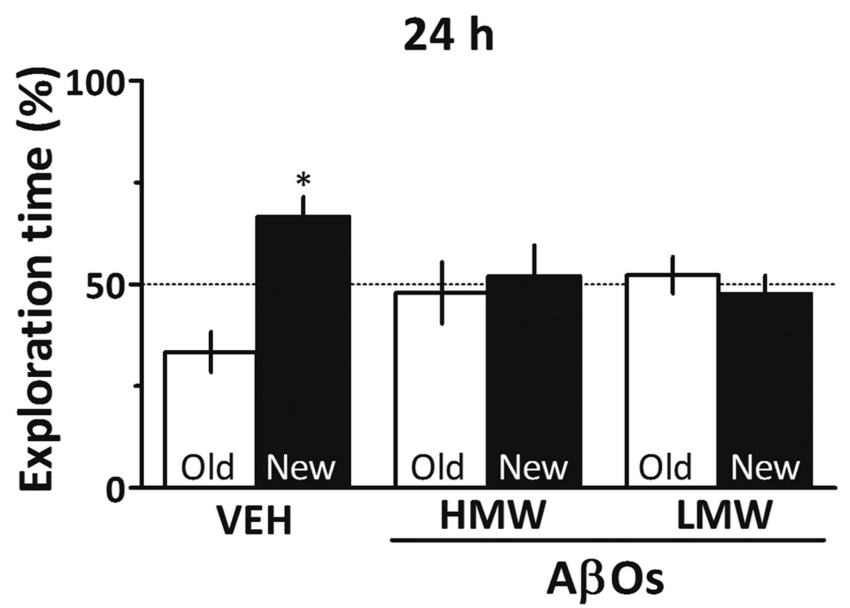

D

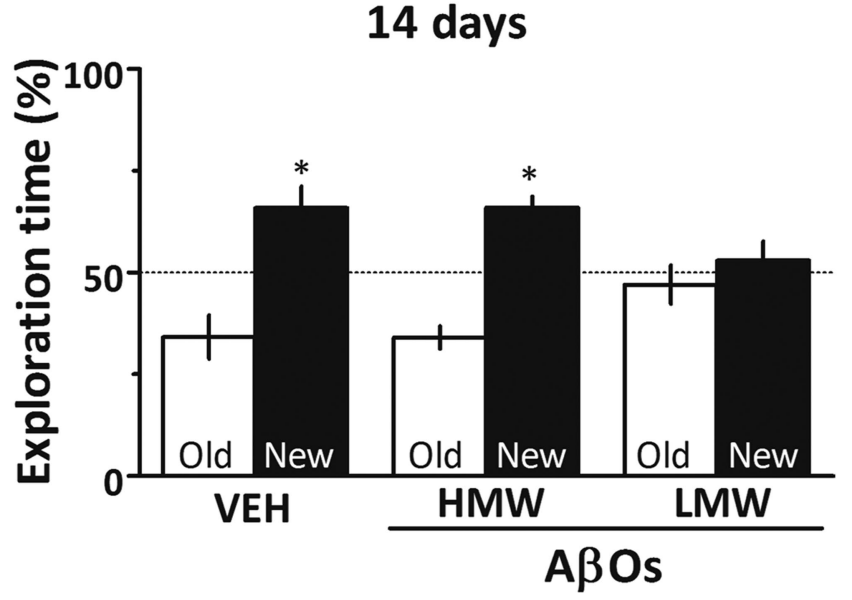

Figure 2. LMW A $\beta 0$ s, but not HMW A $\beta 0$ s, induce persistent cognitive impairment. $\boldsymbol{A}$, HPLC size-exclusion chromatography revealed that oligomer preparations comprised two major peaks that were isolated and characterized by dot blot (left inset) and Western immunoblotting (right inset). High-molecular-weight A $\beta 0$ s are the major components in fraction 1 , while low-molecular-weight oligomers constitute the majority of fraction 2. B-D, Mice received a single intracerebroventricular injection of $10 \mathrm{pmol}$ of fractionated HMW A $\beta 0$ s, LMW A $\beta 0$ s or vehicle (VEH) and were tested in the object recognition task $24 \mathrm{~h}(\boldsymbol{B}), 7 \mathrm{~d}(\boldsymbol{C})$, or $14 \mathrm{~d}(\boldsymbol{D})$ after injection. Error bars represent means \pm SEM ( $n=10$ mice/group) of time spent on the novel (black bars) or familiar (white bars) objects. ${ }^{*} p<0.05$ (statistically significant difference; one-sample Student's $t$ test).

was detected in hippocampal extracts from $\mathrm{A} \beta \mathrm{O}$-injected animals (Fig. 1D).

\section{LMW but not HMW A $\beta O$ s induce persistent memory impairment in mice}

We next tested the effects of different $\mathrm{A} \beta \mathrm{O}$ assemblies on memory. To this end, $A \beta O$ preparations were fractionated by SEC HPLC into two fractions corresponding to highmolecular-weight (molecular mass ranging from $\sim 80$ to $150 \mathrm{kDa}$ ) and low-molecular-weight oligomers (average molecular mass, $\sim 10 \mathrm{kDa}$ ) (Fig. $2 A$ ). The isolated fractions (corresponding to $10 \mathrm{pmol} \mathrm{A} \beta \mathrm{Os}$ ) were then injected intracerebroventricularly in mice, and animals were evaluated in the OR test. Both HMW and LMW oligomer fractions impaired memory when animals were tested $24 \mathrm{~h}$ (Fig. $2 \mathrm{~B}$ ) or $7 \mathrm{~d}$ after injection (Fig. 2C). Interestingly, $14 \mathrm{~d}$ after injection, only LMW $\mathrm{A} \beta \mathrm{O}$-injected mice remained cognitively impaired, while HMW A $\beta \mathrm{O}$-injected mice had fully recovered and exhibited normal performance in the OR test (Fig. 2D). Additional experiments showed that memory impairment induced by LMW oligomers, as well as by nonfractionated oligomers, persisted for at least $21 \mathrm{~d}$ after injection (data not shown).

Synapse pathology induced by intracerebroventricularly injected $\mathrm{A} \boldsymbol{\beta} \mathrm{Os}$

We showed previously that exposure of hippocampal neuronal cultures and ex vivo human cortical slices to sublethal concentrations of $A \beta O$ s downregulates the presynaptic protein synaptophysin at both mRNA and protein levels (Sebollela et al., 2012). To investigate the molecular mechanisms involved in $\mathrm{A} \beta \mathrm{O}$ induced memory impairment, we examined hippocampal levels of synaptophysin $14 \mathrm{~d}$ after intracerebroventricular injection of $\mathrm{A} \beta \mathrm{O}$ s (Fig. $3 A-M$ ). This time point was chosen because it discriminates between the reversible effect of HMW oligomers and the persistent impact of LMW oligomers on memory. Injection of LMW A $\beta$ Os resulted in decreased synaptophysin levels in CA1, $\mathrm{CA} 3$, and dentate gyrus, while no changes in synaptophysin levels were detected in any of the hippocampal fields examined in HMW A $\beta O$-injected mice. 

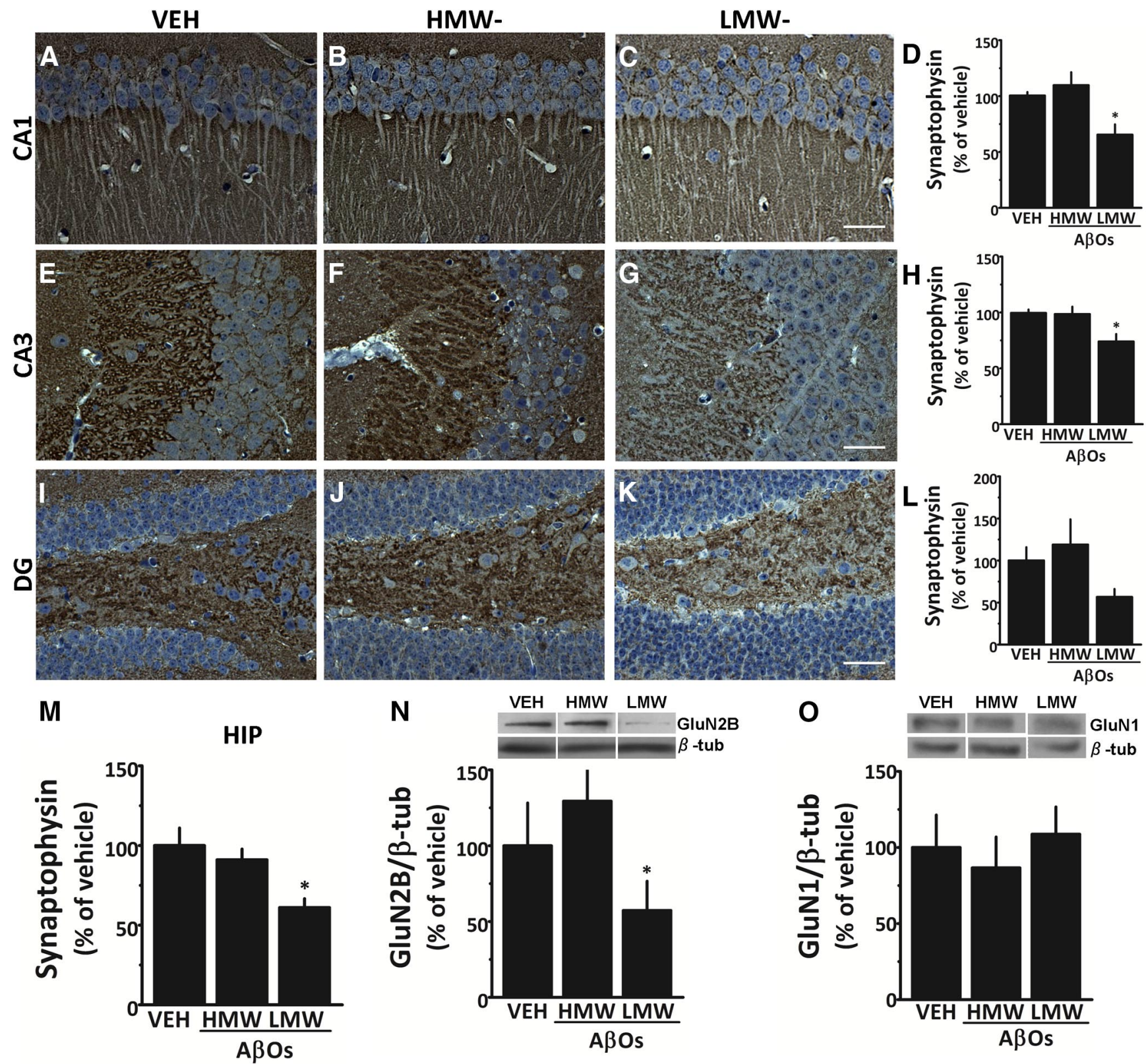

Figure 3. LMW A $\beta 0$ s induce hippocampal synapse pathology in mice. Synaptophysin immunoreactivity was examined $14 \mathrm{~d}$ after intracerebroventricular injection of $10 \mathrm{pmol} H M W \mathrm{~A} \beta 0 \mathrm{~s}$, LMW $A \beta 0$ s, or vehicle (VEH). $\boldsymbol{A}-\boldsymbol{L}$, Representative images are shown for CA1 $(\boldsymbol{A}-\boldsymbol{C}), \mathrm{CA} 3(\boldsymbol{E}-\boldsymbol{G})$, and dentate gyrus (DG; $\boldsymbol{I} \boldsymbol{K})$ hippocampal subfields. Scale bars: $50 \mu \mathrm{m}$. Graphs show integrated synaptophysin immunoreactivity (optical density) in $C A 1(\boldsymbol{D}), C A 3(\boldsymbol{H})$, and dentate gyrus $(\boldsymbol{L})$. Error bars represent means \pm SEM of integrated optical densities in three images per animal $(n=5-8$ mice/group). $M$, Integrated synaptophysin immunoreactivity for the entire hippocampus ( $n=5-8$ mice/group). Western immunoblots for GluN2B and GluN1 subunit-containing NMDAR in mouse hippocampal extracts $14 \mathrm{~d}$ after intracerebroventricular injection of $10 \mathrm{pmol}$ HMW A $\beta 0$ s, LMW A $\beta 0$ s, or vehicle. $\boldsymbol{N}, \mathbf{0}$, Graphs show densitometric quantification of GluN2B ( $\boldsymbol{N}$ ) and GluN1 (0) levels normalized by $\beta$-tubulin. ${ }^{*} p<0.05$ (statistically significant difference; one-way ANOVA followed by Dunnett's test comparing means of different experimental groups with vehicle-injected mice).

NMDA receptors (NMDARs) play a major role in synaptic plasticity (Bashir et al., 1991; Murphy et al., 1997), and recent evidence indicates that $\mathrm{A} \beta \mathrm{O}$ s aberrantly activate GluN2Bcontaining NMDARs, thereby impairing synaptic plasticity in mouse hippocampal slices (Li et al., 2011; Kervern et al., 2012). Thus, we next investigated the impact of distinct $A \beta$ assemblies on GluN2B levels in the mouse hippocampus. Significantly reduced GluN2B immunoreactivity was found in hippocampi from LMW A $\beta \mathrm{O}$-injected mice $14 \mathrm{~d}$ after injection, but not in hippocampi from $\mathrm{HMW} \mathrm{A} \beta \mathrm{O}$-injected animals (Fig. $3 N$ ). No changes in total GluN1 levels were found in hippocampi from either LMW or HMW A $\beta \mathrm{O}$-injected mice (Fig. 3O). These results demonstrate that LMW A $\beta$ Os induce a persistent synaptic im- pact in the hippocampus, with marked reductions in both presynaptic (synaptophysin) and postsynaptic (GluN2B) proteins involved in neurotransmission and synaptic plasticity.

LMW A $\beta O$ s reduce surface expression of GluN1 in cultured hippocampal neurons

Previous studies have shown that $A \beta O$ s induce internalization of GluN1-containing NMDARs in cultured hippocampal neurons (Snyder et al., 2005; Lacor et al., 2007; De Felice et al., 2009; Jurgensen et al., 2011) without affecting total cellular levels of GluN1 (Jurgensen et al., 2011). This raised the possibility that internalization of GluN1 might be involved in the differential impact of HMW and LMW A $\beta$ Os, despite our finding that total 

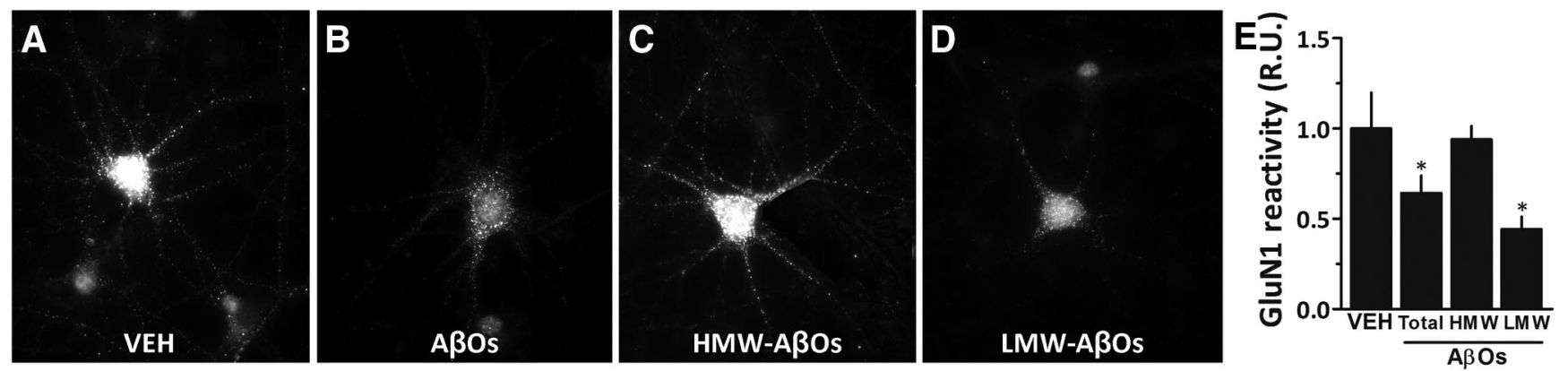

Figure 4. LMW A $\beta 0$ s induce a decrease in surface immunoreactivity of GluN1. $A-D$, Cultured hippocampal neurons were exposed for 3 h at $37^{\circ} \mathrm{C}$ to vehicle (VEH; $A$ ), $500 \mathrm{~nm} A \beta 0$ s (unfractionated oligomers; $\boldsymbol{B}), 500 \mathrm{~nm}$ HMW A $\beta 0 \mathrm{~s}(\boldsymbol{C})$, or $500 \mathrm{~nm}$ LMW A $\beta 0 \mathrm{~s}(\boldsymbol{D})$. Immunocytochemistry in nonpermeabilized cells was performed using an antibody against an extracellular epitope of the GluN1 subunit of NMDARs. $\boldsymbol{E}$, Integrated GluN1 immunoreactivity. Error bars show means \pm SEM for data from two experiments with independent neuronal cultures (3 coverslips per experimental condition, 10 images per coverslip in each experiment). ${ }^{*} p<0.05$ (statistically significant difference; one-way ANOVA followed by Dunnett's test comparing means of different experimental groups with vehicle-injected control animals). R.U., relative units.
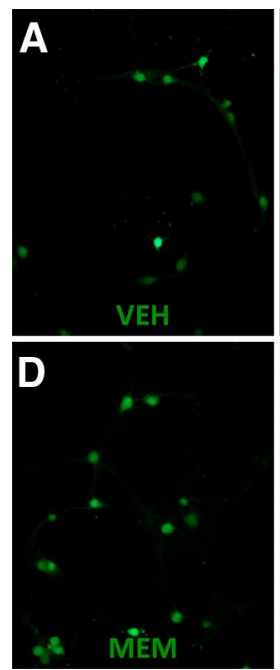
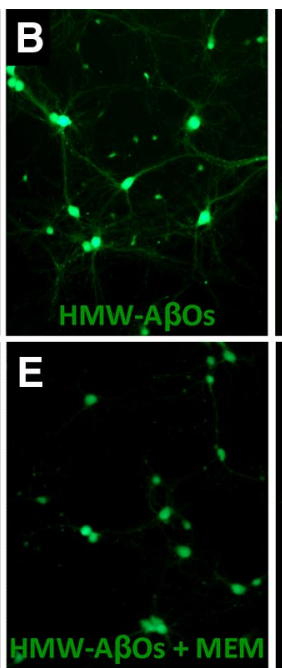
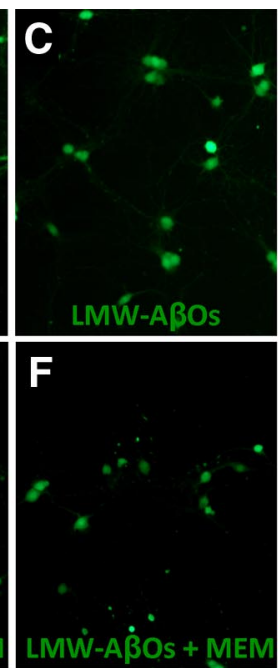

G

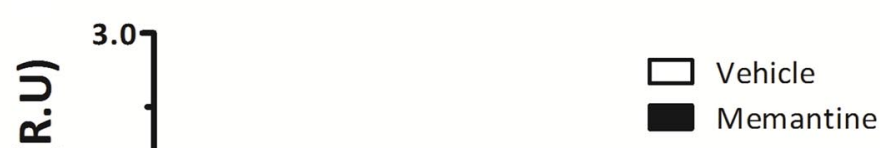

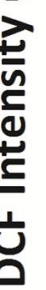

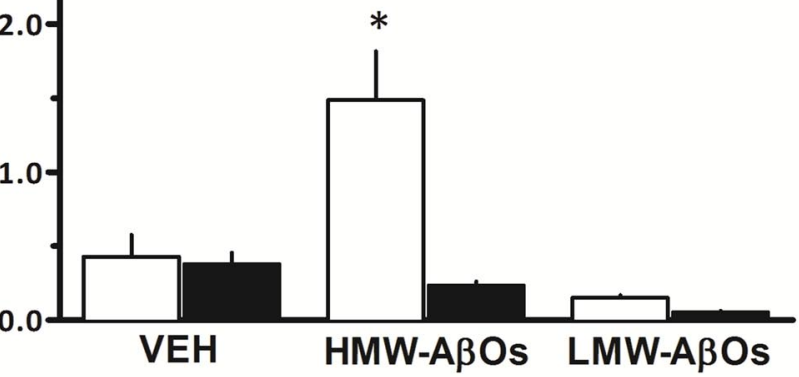

Figure 5. HMW A $\beta 0$ s induce excessive ROS generation in hippocampal neurons. $\boldsymbol{A}-\boldsymbol{F}$, Representative $D C F$ fluorescence images in hippocampal cultures exposed to vehicle (VEH; $\boldsymbol{A}), 500 \mathrm{~nm} H \mathrm{HMW}$ A $\beta 0 \mathrm{~s}(\boldsymbol{B}), 500 \mathrm{~nm} \mathrm{LMW} \mathrm{A} \beta 0 \mathrm{~s}(\boldsymbol{C}$, memantine (MEM; $\boldsymbol{D}), 500 \mathrm{~nm} \mathrm{HMW} \mathrm{A} \beta 0$ s plus memantine $(\boldsymbol{E})$, or $500 \mathrm{~nm}$ LMW A $\beta 0$ s plus memantine $(\boldsymbol{F})$. When present, memantine (10 $\mu \mathrm{M})$ was added 30 min before $A \beta 0$ s. To allow direct comparison of ROS levels, identical conditions and exposure times for image acquisition were used for all experimental conditions. $G$, Integrated DCF fluorescence from experiments with two independent cultures. ${ }^{*} p<0.05$ (statistically significant difference; one-way ANOVA followed by Dunnett's test comparing means of different experimental groups with vehicle-treated control cultures).

GluN1 levels were unaffected in hippocampi from oligomerinjected mice. To test this hypothesis, hippocampal neurons in culture were exposed to LMW A $\beta O$ s, HMW A $\beta$ Os, or nonfractionated $\mathrm{A} \beta \mathrm{O}$ s, and surface GluN1 levels were quantified in oligomer-attacked neurons (Fig. 4). In line with the studies cited above, exposure of neurons to nonfractionated $\mathrm{A} \beta \mathrm{O}$ s resulted in decreased surface levels of GluN1. Results further showed that LMW A $\beta$ Os decreased surface expression of GluN1 in hippocampal neurons, whereas surface GluN1 levels in hippocampal neurons exposed to HMW A $\beta O$ s were comparable to those in vehicle-treated neurons. These findings suggest that internalization of GluN1 may be an additional mechanism by which LMW $\mathrm{A} \beta \mathrm{O}$ s induce persistent memory deficit in mice.

\section{HMW A $\beta$ Os induce excessive ROS generation in}

\section{hippocampal neurons}

Transient production of ROS plays a role in synaptic signaling, with ROS acting as messenger molecules in long-term potentiation (LTP) (for review, see Serrano and Klann, 2004). On the other hand, excessive ROS levels are deleterious to synaptic plasticity and, ultimately, to neuronal survival. We showed previ- ously that $\mathrm{A} \beta \mathrm{O}$ s stimulate excessive neuronal ROS generation in an NMDAR-dependent manner (De Felice et al., 2007; Lambert et al., 2007; Decker et al., 2010a; Paula-Lima et al., 2011). To determine whether different $\mathrm{A} \beta \mathrm{O}$ fractions similarly induce ROS formation, mature hippocampal neuronal cultures were exposed to either HMW or LMW A $\beta$ Os, and ROS levels were assessed using the ROS-sensitive probe DCFDA (Fig. 5). Neurons exposed to $\mathrm{HMW} \mathrm{A} \beta \mathrm{O}$ s displayed a prominent increase in DCF fluorescence compared to vehicle-treated neurons. In contrast, no increase in ROS production was detected in hippocampal neurons exposed to LMW A $\beta$ Os. Significantly, ROS formation induced by HMW A $\beta$ Os was prevented by pretreatment with the NMDAR open-channel blocker memantine. These findings suggest that NMDAR-mediated oxidative stress induced by HMW A $\beta O$ s could, at least in part, underlie the transient cognitive deficit observed in HMW A $\beta \mathrm{O}$-injected mice.

Memantine rescues the transient memory impairment induced by $\mathrm{HMW} \mathrm{A} \beta \mathrm{Os}$

Given the role of NMDARs in A $\beta \mathrm{O}$-induced neuronal oxidative stress (De Felice et al., 2007) and synapse dysfunction (for review, 
see Ferreira and Klein, 2011), and our finding that memantine prevents HMW $\mathrm{A} \beta \mathrm{O}$-induced ROS generation, we sought to determine whether memantine might rescue the memory deficit in oligomerinjected mice. Because the memantine dose range that is effective in rodents and AD patients remains somewhat controversial (Creeley et al., 2006; Beconi et al. 2011), we initially investigated the effects of different doses of memantine alone on the object recognition test in mice. While 2 and $10 \mathrm{mg} / \mathrm{kg}$ memantine alone had no effect on memory, administration of 20 $\mathrm{mg} / \mathrm{kg}$ memantine clearly induced cognitive impairment in mice (Fig. 6A), limiting the memantine dose to $10 \mathrm{mg} / \mathrm{kg}$ in subsequent experiments. Compared to animals that received intracerebroventricular HMW A $\beta O$ s alone, animals that received $\mathrm{HMW} \mathrm{A} \beta \mathrm{O}$ s and were treated with $2 \mathrm{mg} / \mathrm{kg}$ memantine exhibited a trend of improvement in object recognition memory $(p=0.085)$, while treatment with $10 \mathrm{mg} / \mathrm{kg}$ memantine blocked HMW A $\beta \mathrm{O}$-induced cognitive impairment (Fig. 6B). Interestingly, however, 10 $\mathrm{mg} / \mathrm{kg}$ memantine did not prevent cognitive impairment caused by LMW A $\beta \mathrm{O}$ (Fig. 6C). This suggests that aberrant activation of NMDARs underlies memory impairment induced by HMW A $\beta O$ s, but not by LMW oligomers.

Additional evidence indicating that memantine rescued HMW A $\beta \mathrm{O}$-induced cognitive impairment by blocking abnormal activation of NMDARs was provided by the finding that a similar protection was obtained with a low dose $(0.1 \mathrm{mg} / \mathrm{kg}$, which per se had no effect on memory) of MK-801, a highaffinity NMDAR channel blocker (Fig. 6D).

\section{Discussion}

At present, it is uncertain whether one type of $\mathrm{A} \beta \mathrm{O}$ s is more germane to the pathogenesis of $\mathrm{AD}$ than another. It is unlikely that a single oligomer species is responsible for the complex impact on plasticity-related receptors and global dysregulation of intracellular signaling pathways that takes place in $\mathrm{AD}$. It is reasonable to expect that distinct $A \beta$ assemblies may differentially affect pathways causing synaptic and network dysfunction (Mucke and Selkoe, 2012). Since $A \beta$ oligomeric species act on independent targets at different stages of $\mathrm{AD}$, it has been challenging to establish the mechanism of toxicity of each particular fraction. This is, at least in part, due to the fact that oligomer preparations typically comprise heterogeneous mixtures of low-molecular-weight (dimers, trimers, tetramers) and high-molecular-weight (dodecamers or larger) $\mathrm{A} \beta$ assemblies, and different preparations differ substantially in terms of the proportion of low-/high-molecularweight species (Bernstein et al., 2009; Benilova and De Strooper, 2011; Benilova et al., 2012; Larson et al., 2012). Moreover, oligomers have been tested in a variety of experimental conditions (including different oligomer concentrations, cell types, extents of maturation of neuronal cultures, etc.), making it difficult to directly compare results from different studies.
B

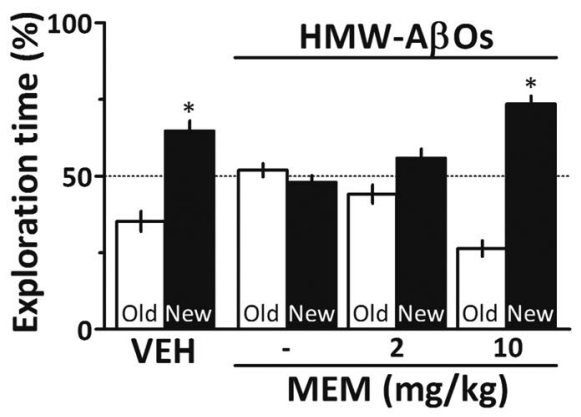

D

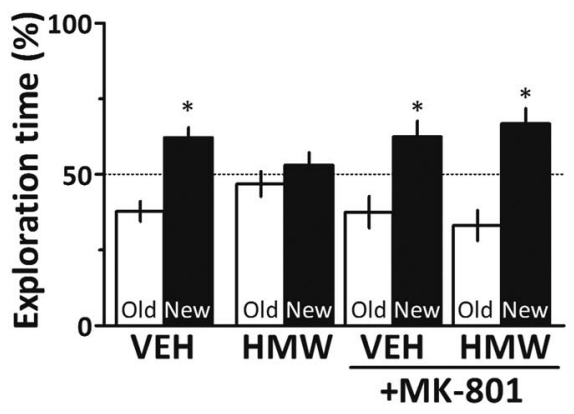

Figure 6. $\quad$ NMDA receptor blockade rescues $H M W A \beta 0$-induced memory impairment. $\boldsymbol{A}$, Mice were treated daily by gavage with 2,10 , or $20 \mathrm{mg} / \mathrm{kg}$ memantine (MEM) for $7 \mathrm{~d}$ before testing in the object recognition paradigm ( $n=7-9$ mice/group). $\boldsymbol{B}$, Mice

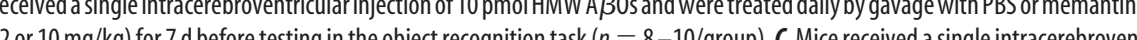
列 (statistically significant difference; one-sample Student's $t$ test). VEH, Vehicle.

We now report that intracerebroventricularly injected $\mathrm{A} \beta \mathrm{O}$ s (10 pmol) diffused in the brain, reached the hippocampus, and induced long-lasting memory impairment in the novel object recognition test, a task that involves activation of the hippocampus and other brain regions (Broadbent et al., 2010; Clarke et al., 2010). By SEC fractionating $A \beta O$ s according to their size, we were able to determine the impact of $\mathrm{A} \beta \mathrm{O}$ s of different molecular masses on synaptic integrity and memory. Mice that received LMW A $\beta O$ s developed persistent cognitive impairment for as long as evaluated (up to $21 \mathrm{~d}$ after injection). On the other hand, HMW oligomer-injected mice suffered transient memory impairment, but recovered cognitive performance by $14 \mathrm{~d}$ after intracerebroventricular injection. Notably, only LMW A $\beta$ Os exerted a major impact on hippocampal synaptic density, as demonstrated by decreased synaptophysin levels. Synapse loss has been found to be a better structural correlate of dementia than other brain lesions (Masliah et al., 1991; Terry et al., 1991; Lassmann et al., 1993), and our current results indicate a direct connection between synapse pathology and $\mathrm{A} \beta$ oligomer activity in $\mathrm{AD}$.

Consistent with our findings, $A \beta$ dimers, trimers, and tetramers inhibit hippocampal LTP (Walsh et al., 2005; Townsend et al., 2006; Shankar et al., 2007, 2008; Klyubin et al., 2008; Jin et al., 2011), induce tau hyperphosphorylation in cultured neurons (Larson and Lesne, 2012), and cause decreases in hippocampal levels of synaptic proteins (Brouillette et al., 2012). Moreover, by comparing the effects of intracerebroventricular injections of different sized $A \beta O$ s in rats, Reed et al. (2011) found that lower doses of dimer-enriched 
preparations were required to cause memory impairment compared to HMW oligomer-enriched fractions.

Previous studies have shown that $\mathrm{A} \beta \mathrm{O}$ s trigger internalization of NMDARs from the neuronal surface (Snyder et al., 2005; Lacor et al., 2007; Shankar et al., 2007; De Felice et al., 2009; Jurgensen et al., 2011). Our current results indicate that oligomers of distinct sizes differentially impact NMDARs. Decreased levels of the NMDAR subunit GluN2B were found in the hippocampus of LMW A $\beta \mathrm{O}$-injected mice, but not in HMW A $\beta \mathrm{O}$-injected animals. Furthermore, LMW oligomers, but not HMW oligomers, caused internalization of the GluN1 NMDAR subunit in hippocampal neurons. Thus, LMW oligomers impact surface levels and subunit composition of NMDARs, and are associated with persistent cognitive impairment.

While a reduction in surface NMDARs can be directly linked to impaired neuronal transmission and long-term potentiation, overactivation of NMDARs is known to cause excessive calcium influx and production of ROS. Aberrant activation of NMDARs has been shown to mediate the neurotoxicity of $\mathrm{A} \beta \mathrm{O}$ s (De Felice et al., 2007; Lambert et al., 2007; Decker et al., 2010a,b). Herein, we have shown that this central feature of oligomer-induced toxicity can be attributed to the impact of HMW oligomers on neurons, as isolated LMW A $\beta O$ s failed to exacerbate ROS generation in cultured hippocampal neurons. Given the important roles of ROS as physiological signaling molecules in synaptic plasticity (Serrano and Klann, 2004), deregulation of neuronal ROS levels by HMW A $\beta O$ s may underlie the transient memory impairment induced by these oligomers.

Oxidative stress mediates, at least in part, glutamate receptor-mediated neuronal cell injury and death (Murphy and Baraban, 1990; Ankarcrona et al., 1995). A mechanism that could potentially curtail excessive $\mathrm{Ca}^{2+}$ influx, and the subsequent formation of neurotoxic ROS, is inhibition of NMDAR hyperactivation. Memantine, an NMDAR openchannel blocker used in $\mathrm{AD}$ treatment, preferentially blocks excessive (pathological/extrasynaptic) NMDAR activity while relatively sparing normal (physiological/synaptic) activity (Chen et al., 1992). In vitro and in vivo studies using animal models of neurodegenerative diseases and stroke showed that memantine protects neurons from NMDAR-mediated excitotoxic damage (Xia et al., 2010). However, since its introduction into clinical practice for treating $\mathrm{AD}$ in the past decade, reports on the therapeutic benefit indicate a modest and transient efficacy in delaying cognitive decline in AD (Schneider et al., 2011). Therefore, it remains unclear why in vitro neuprotection by memantine does not translate into greater clinical efficacy.

We found that memantine treatment had no effect on memory deficit induced by LMW A $\beta$ Os, likely due to the fact that the impact of LMW A $\beta$ Os is related to decreased synaptophysin and surface GluN1 levels. On the other hand, memantine effectively rescued memory impairment induced by HMW A $\beta O$ s, as well as ROS produced by HMW $A \beta O s$ in hippocampal neurons. It is important to note that, in addition to blocking NMDARs, memantine might also act on other neurotransmitter systems, e.g., as a muscarinic receptor agonist (Drever et al., 2007). However, two lines of evidence indicate that the protective effect of memantine against HMW A $\beta \mathrm{O}$-induced memory impairment was mediated by NMDAR blockade. First, similar protection was verified using the high-affinity NMDAR blocker MK-801. Second, under our experimental conditions, memantine was unable to prevent memory impairment induced by scopolamine, a muscarinic receptor antagonist (data not shown).

Together, our findings support the notion that both LMW and HMW oligomers have toxic effects on neurons, and that their combined toxicity translates into the classical clinical symptoms of $\mathrm{AD}$ including persistent cognitive impairment. LMW $\mathrm{A} \beta \mathrm{O}$ induce GluN1 internalization, loss of the presynaptic protein synaptophysin, and persistent cognitive impairment that is not sensitive to memantine. On the other hand, HMW oligomers induce excessive ROS formation in hippocampal neurons and transient cognitive deficit that can be prevented by memantine. In conclusion, current results offer an explanation for the limited clinical efficacy of memantine and suggest that, in addition to preventing HMW oligomer-induced aberrant activation of NMDARs, targeting LMW oligomers to prevent persistent synaptic pathology may result in improved therapeutics for AD.

\section{References}

Ankarcrona M, Dypbukt JM, Bonfoco E, Zhivotovsky B, Orrenius S, Lipton SA, Nicotera P (1995) Glutamate-induced neuronal death: a succession of necrosis or apoptosis depending on mitochondrial function. Neuron 15:961-973. CrossRef Medline

Bashir ZI, Alford S, Davies SN, Randall AD, Collingridge GL (1991) Longterm potentiation of NMDA receptor-mediated synaptic transmission in the hippocampus. Nature 349:156-158. CrossRef Medline

Beconi MG, Howland D, Park L, Lyons K, Giuliano J, Dominguez C, MunozSanjuan I, Pacifici R (2011) Pharmacokinetics of memantine in rats and mice. PLoS Curr 3:RRN1291. CrossRef Medline

Benilova I, De Strooper B (2011) An overlooked neurotoxic species in Alzheimer's disease. Nat Neurosci 14:949-950. CrossRef Medline

Benilova I, Karran E, De Strooper B (2012) The toxic Abeta oligomer and Alzheimer's disease: an emperor in need of clothes. Nat Neurosci 15:349357. CrossRef Medline

Bernstein SL, Dupuis NF, Lazo ND, Wyttenbach T, Condron MM, Bitan G, Teplow DB, Shea JE, Ruotolo BT, Robinson CV, Bowers MT (2009) Amyloid-beta protein oligomerization and the importance of tetramers and dodecamers in the aetiology of Alzheimer's disease. Nat Chem 1:326331. CrossRef Medline

Broadbent NJ, Gaskin S, Squire LR, Clark RE (2010) Object recognition memory and the rodent hippocampus. Learn Mem 17:5-11. CrossRef Medline

Brouillette J, Caillierez R, Zommer N, Alves-Pires C, Benilova I, Blum D, De Strooper B, Buée L (2012) Neurotoxicity and memory deficits induced by soluble low-molecular-weight amyloid-beta1-42 oligomers are revealed in vivo by using a novel animal model. J Neurosci 32:7852-7861. CrossRef Medline

Chen HS, Pellegrini JW, Aggarwal SK, Lei SZ, Warach S, Jensen FE, Lipton SA (1992) Open-channel block of N-methyl-D-aspartate (NMDA) responses by memantine: therapeutic advantage against NMDA receptormediated neurotoxicity. J Neurosci 12:4427-4436. Medline

Chromy BA, Nowak RJ, Lambert MP, Viola KL, Chang L, Velasco PT, Jones BW, Fernandez SJ, Lacor PN, Horowitz P, Finch CE, Krafft GA, Klein WL (2003) Self-assembly of Abeta (1-42) into globular neurotoxins. Biochemistry 42:12749-12760. CrossRef Medline

Clarke JR, Cammarota M, Gruart A, Izquierdo I, Delgado-García JM (2010) Plastic modifications induced by object recognition memory processing. Proc Natl Acad Sci U S A 107:2652-2657. CrossRef Medline

Creeley C, Wozniak DF, Labruyere J, Taylor GT, Olney JW (2006) Low doses of memantine disrupt memory in adult rats. J Neurosci 26:39233932. CrossRef Medline

da-Silva WS, Gómez-Puyou A, de Gómez-Puyou MT, Moreno-Sanchez R, De Felice FG, de Meis L, Oliveira MF, Galina A (2004) Mitochondrial bound hexokinase activity as a preventive antioxidant defense: steadystate ADP formation as a regulatory mechanism of membrane potential and reactive oxygen species generation in mitochondria. J Biol Chem 279:39846-39855. CrossRef Medline

Decker H, Jurgensen S, Adrover MF, Brito-Moreira J, Bomfim TR, Klein WL, Epstein AL, De Felice FG, Jerusalinsky D, Ferreira ST (2010a) N-methylD-aspartate receptors are required for synaptic targeting of Alzheimer's toxic amyloid-beta peptide oligomers. J of neurochemistry 115:1520 1529. CrossRef

Decker H, Lo KY, Unger SM, Ferreira ST, Silverman MA (2010b) Amyloidbeta oligomers disrupt axonal transport through an NMDA receptor- 
dependent mechanism that is mediated by glycogen synthase kinase 3 beta in primary cultured hippocampal neurons. J Neurosci 30:9166-9171. Medline

De Felice FG, Velasco PT, Lambert MP, Viola K, Fernandez SJ, Ferreira ST, Klein WL (2007) Abeta oligomers induce neuronal oxidative stress through an $\mathrm{N}$-methyl-D-aspartate receptor-dependent mechanism that is blocked by the Alzheimer drug memantine. J Biol Chem 282:1159011601. CrossRef Medline

De Felice FG, Vieira MN, Bomfim TR, Decker H, Velasco PT, Lambert MP, Viola KL, Zhao WQ, Ferreira ST, Klein WL (2009) Protection of synapses against Alzheimer's-linked toxins: insulin signaling prevents the pathogenic binding of Abeta oligomers. Proc Natl Acad Sci U S A 106: 1971-1976. CrossRef Medline

Drever BD, Anderson WG, Johnson H, O'Callaghan M, Seo S, Choi DY, Riedel G, Platt B (2007) Memantine acts as a cholinergic stimulant in the mouse hippocampus. J Alzheimers Dis 12:319-333. Medline

Ferreira ST, Klein WL (2011) The Abeta oligomer hypothesis for synapse failure and memory loss in Alzheimer's disease. Neurobiol Learn Mem 96:529-543. CrossRef Medline

Ferreira ST, Vieira MN, De Felice FG (2007) Soluble protein oligomers as emerging toxins in Alzheimer's and other amyloid diseases. IUBMB Life 59:332-345. CrossRef Medline

Figueiredo CP, Bicca MA, Latini A, Prediger RD, Medeiros R, Calixto JB (2011) Folic acid plus alpha-tocopherol mitigates amyloid-beta-induced neurotoxicity through modulation of mitochondrial complexes activity. J Alzheimers Dis 24:61-75. Medline

Glabe CG (2008) Structural classification of toxic amyloid oligomers. J Biol Chem 283:29639-29643. CrossRef Medline

Gong Y, Chang L, Viola KL, Lacor PN, Lambert MP, Finch CE, Krafft GA, Klein WL (2003) Alzheimer's disease-affected brain: presence of oligomeric A beta ligands (ADDLs) suggests a molecular basis for reversible memory loss. Proc Natl Acad Sci U S A 100:10417-10422. CrossRef Medline

Haass C, Selkoe DJ (2007) Soluble protein oligomers in neurodegeneration: lessons from the Alzheimer's amyloid beta-peptide. Nat Rev Mol Cell Biol 8:101-112. CrossRef Medline

Jin M, Shepardson N, Yang T, Chen G, Walsh D, Selkoe DJ (2011) Soluble amyloid beta-protein dimers isolated from Alzheimer cortex directly induce Tau hyperphosphorylation and neuritic degeneration. Proc Natl Acad Sci U S A 108:5819-5824. CrossRef Medline

Jürgensen S, Antonio LL, Mussi GE, Brito-Moreira J, Bomfim TR, De Felice FG, Garrido-Sanabria ER, Cavalheiro EA, Ferreira ST (2011) Activation of D1/D5 dopamine receptors protects neurons from synapse dysfunction induced by amyloid-beta oligomers. J Biol Chem 286:3270-3276. CrossRef Medline

Kervern M, Angeli A, Nicole O, Léveillé F, Parent B, Villette V, Buisson A, Dutar P (2012) Selective impairment of some forms of synaptic plasticity by oligomeric amyloid-beta peptide in the mouse hippocampus: implication of extrasynaptic NMDA receptors. J Alzheimers Dis 32:183-196. Medline

Klyubin I, Betts V, Welzel AT, Blennow K, Zetterberg H, Wallin A, Lemere CA, Cullen WK, Peng Y, Wisniewski T, Selkoe DJ, Anwyl R, Walsh DM, Rowan MJ (2008) Amyloid beta protein dimer-containing human CSF disrupts synaptic plasticity: prevention by systemic passive immunization. J Neurosci 28:4231-4237. CrossRef Medline

Lacor PN, Buniel MC, Chang L, Fernandez SJ, Gong Y, Viola KL, Lambert MP, Velasco PT, Bigio EH, Finch CE, Krafft GA, Klein WL (2004) Synaptic targeting by Alzheimer's related amyloid beta oligomers. J Neurosci 24:10191-10200. CrossRef Medline

Lacor PN, Buniel MC, Furlow PW, Clemente AS, Velasco PT, Wood M, Viola KL, Klein WL (2007) Abeta oligomer-induced aberrations in synapse composition, shape, and density provide a molecular basis for loss of connectivity in Alzheimer's disease. J Neurosci 27:796-807. CrossRef Medline

Lambert MP, Barlow AK, Chromy BA, Edwards C, Freed R, Liosatos M, Morgan TE, Rozovsky I, Trommer B, Viola KL, Wals P, Zhang C, Finch CE, Krafft GA, Klein WL (1998) Diffusible, nonfibrillar ligands derived from Abeta1-42 are potent central nervous system neurotoxins. Proc Natl Acad Sci U S A 95:6448-6453. CrossRef Medline

Lambert MP, Velasco PT, Chang L, Viola KL, Fernandez S, Lacor PN, Khuon D, Gong Y, Bigio EH, Shaw P, De Felice FG, Krafft GA, Klein WL (2007)
Monoclonal antibodies that target pathological assemblies of Abeta. J Neurochem 100:23-35. CrossRef Medline

Larson ME, Lesne SE (2012) Soluble Abeta oligomer production and toxicity. J Neurochem 120 [Suppl 1]:125-139.

Larson M, Sherman MA, Amar F, Nuvolone M, Schneider JA, Bennett DA, Aguzzi A, Lesné SE (2012) The complex PrP(c)-Fyn couples human oligomeric Abeta with pathological tau changes in Alzheimer's disease. J Neurosci 32:16857-16871a. CrossRef Medline

Lassmann H, Fischer P, Jellinger K (1993) Synaptic pathology of Alzheimer's disease. Ann N Y Acad Sci 695:59-64. CrossRef

Laursen SE, Belknap JK (1986) Intracerebroventricular injections in mice. Some methodological refinements. J Pharmacol Methods 16:355-357. CrossRef Medline

Li S, Jin M, Koeglsperger T, Shepardson NE, Shankar GM, Selkoe DJ (2011) Soluble Abeta oligomers inhibit long-term potentiation through a mechanism involving excessive activation of extrasynaptic NR2B-containing NMDA receptors. J Neurosci 31:6627-6638. CrossRef Medline

Masliah E, Hansen L, Albright T, Mallory M, Terry RD (1991) Immunoelectron microscopic study of synaptic pathology in Alzheimer's disease. Acta Neuropathol 81:428-433. CrossRef Medline

Mucke L, Selkoe DJ (2012) Neurotoxicity of amyloid beta-protein: synaptic and network dysfunction. Cold Spring Harb Perspect Med 2:a006338. Medline

Murphy KP, Reid GP, Trentham DR, Bliss TV (1997) Activation of NMDA receptors is necessary for the induction of associative long-term potentiation in area CA1 of the rat hippocampal slice. J Physiol 504:379-385. CrossRef Medline

Murphy TH, Baraban JM (1990) Glutamate toxicity in immature cortical neurons precedes development of glutamate receptor currents. Brain Res Dev Brain Res 57:146-150. CrossRef Medline

Paula-Lima AC, Adasme T, SanMartín C, Sebollela A, Hetz C, Carrasco MA, Ferreira ST, Hidalgo C (2011) Amyloid beta-peptide oligomers stimulate RyR-mediated $\mathrm{Ca} 2+$ release inducing mitochondrial fragmentation in hippocampal neurons and prevent RyR-mediated dendritic spine remodeling produced by BDNF. Antioxid Redox Signal 14:1209-1223. CrossRef Medline

Reed MN, Hofmeister JJ, Jungbauer L, Welzel AT, Yu C, Sherman MA, Lesné S, LaDu MJ, Walsh DM, Ashe KH, Cleary JP (2011) Cognitive effects of cell-derived and synthetically derived $\mathrm{A} \beta$ oligomers. Neurobiol Aging 32:1784-1794. CrossRef Medline

Saraiva LM, Seixas da Silva GS, Galina A, da-Silva WS, Klein WL, Ferreira ST, De Felice FG (2010) Amyloid-beta triggers the release of neuronal hexokinase 1 from mitochondria. PloS One 5:e15230. CrossRef Medline

Schneider LS, Dagerman KS, Higgins JP, McShane R (2011) Lack of evidence for the efficacy of memantine in mild Alzheimer disease. Arch Neurol 68:991-998. CrossRef Medline

Sebollela A, Freitas-Correa L, Oliveira FF, Paula-Lima AC, Saraiva LM, Martins SM, Mota LD, Torres C, Alves-Leon S, de Souza JM, Carraro DM, Brentani H, De Felice FG, Ferreira ST (2012) Amyloid-beta oligomers induce differential gene expression in adult human brain slices. J Biol Chem 287:7436-7445. CrossRef Medline

Selkoe DJ (2012) Preventing Alzheimer's disease. Science 337:1488-1492. CrossRef Medline

Serrano F, Klann E (2004) Reactive oxygen species and synaptic plasticity in the aging hippocampus. Ageing Res Rev 3:431-443. CrossRef Medline

Shankar GM, Bloodgood BL, Townsend M, Walsh DM, Selkoe DJ, Sabatini BL (2007) Natural oligomers of the Alzheimer amyloid-beta protein induce reversible synapse loss by modulating an NMDA-type glutamate receptor-dependent signaling pathway. J Neurosci 27:2866-2875. CrossRef Medline

Shankar GM, Li S, Mehta TH, Garcia-Munoz A, Shepardson NE, Smith I, Brett FM, Farrell MA, Rowan MJ, Lemere CA, Regan CM, Walsh DM, Sabatini BL, Selkoe DJ (2008) Amyloid-beta protein dimers isolated directly from Alzheimer's brains impair synaptic plasticity and memory. Nat Med 14:837-842. CrossRef Medline

Snyder EM, Nong Y, Almeida CG, Paul S, Moran T, Choi EY, Nairn AC, Salter MW, Lombroso PJ, Gouras GK, Greengard P (2005) Regulation of NMDA receptor trafficking by amyloid-beta. Nat Neurosci 8:1051-1058. CrossRef Medline

Terry RD, Masliah E, Salmon DP, Butters N, DeTeresa R, Hill R, Hansen LA, Katzman R (1991) Physical basis of cognitive alterations in Alzheimer's 
disease: synapse loss is the major correlate of cognitive impairment. Ann Neurol 30:572-580. CrossRef Medline

Townsend M, Shankar GM, Mehta T, Walsh DM, Selkoe DJ (2006) Effects of secreted oligomers of amyloid beta-protein on hippocampal synaptic plasticity: a potent role for trimers. J Physiol 572:477-492. CrossRef Medline

Walsh DM, Selkoe DJ (2007) A beta oligomers-a decade of discovery. J Neurochem 101:1172-1184. CrossRef Medline
Walsh DM, Klyubin I, Shankar GM, Townsend M, Fadeeva JV, Betts V, Podlisny MB, Cleary JP, Ashe KH, Rowan MJ, Selkoe DJ (2005) The role of cell-derived oligomers of Abeta in Alzheimer's disease and avenues for therapeutic intervention. Biochem Soc Trans 33:1087-1090. CrossRef Medline

Xia P, Chen HS, Zhang D, Lipton SA (2010) Memantine preferentially blocks extrasynaptic over synaptic NMDA receptor currents in hippocampal autapses. J Neurosci 30:11246-11250. CrossRef Medline 